\title{
PEDOMAN SIMBOL HARI BAIK DAN HARI BURUK MASYARAKAT BUGIS DI KOTA KENDARI
}

\section{SYMBOL GUIDELINES OF GOOD AND BAD DAYS OF BUGIS COMMUNITY IN KENDARI}

\begin{abstract}
Fahmi Gunawan
Institut Agama Islam Negeri Kendari

Jalan Sultan Qaimuddin No 17 Baruga Kendari

e-mail: fgunawanp@gmail.com

Abstrak

Hampir semua aktivitas masyarakat Bugis Kendari dimulai dengan mempertimbangkan kualitas waktu yang dikenal dengan istilah hari baik dan hari buruk. Kualitas waktu ini memiliki pedoman dan menggunakan simbol-simbol tertentu. Penelitian ini bertujuan untuk mengkaji simbol hari baik dan hari buruk masyarakat Bugis Kota Kendari. Penelitian ini menggunakan pendekatan deskriptif kualitatif dengan metode studi kasus. Pengumpulan data dilakukan dengan wawancara mendalam dan observasi. Hasil penelitian menunjukkan bahwa pedoman simbol hari baik dan hari buruk masyarakat Bugis di Kota Kendari diklasifikasi menjadi sebelas, yaitu (1) simbol bahasa Arab, (2) simbol matematika, (3) simbol tulisan tangan, (4) Simbol lontara Bugis, (5) simbol lontara Bugis dan gambar, (6) simbol aksara Soewandi, (7) simbol hewan, (8) simbol bintang, (9) simbol bendera, (10) simbol Haji Daud, dan (11) simbol Hj. Nursiah. Penelitian ini akhinrya menegaskan bahwa simbol pedoman ini merepresentasikan masyarakat bugis Kendari yang penuh perencanaan dan memiliki rasa optimisme untuk menggapai hasil maksimal sebuah aktivitas.
\end{abstract}

Kata Kunci: pedoman; smbol hari, baik dan hari buruk.

\begin{abstract}
Almost all activities of the Bugis Kendari community begin by considering the quality of time known as good days and bad days. This quality of time has guidelines and uses certain symbols. This study aims to examine the symbols of good days and bad days of the Bugis people of Kendari city. This study uses a qualitative descriptive approach with a case study method. Data collection is done by in-depth interviews and observations. The results showed that the guideline of the symbol of good days and bad days of Bugis people in Kendari city was classified into eleven, (1) Arabic symbols, (2) mathematical symbols, (3) handwriting symbols, (4) Bugis symbol, (5) Bugis symbols and drawings, (6) Soewandi alphabet symbols, (7) animal symbols, (8) star symbols, (9) flag symbols, (10) Haji Daud symbols, and (11) Hj. Nursiah symbols. This research finally emphasizes that the symbol of this guideline represents the Bugis Kendari community which is full of planning and has a sense of optimism to achieve the maximum results of an activity.
\end{abstract}

Keywords: Guidelines, symbol; good day and bad day.

\section{A. PENDAHULUAN}

Pemilihan hari baik dan hari buruk dalam memulai sebuah aktivitas merupakan fenomena umum yang ditemukan pada masyarakat Bugis di Kota Kendari. Pemilihan hari baik ini tidak hanya terbatas dalam kegiatan keseharian, seperti menempati rumah baru, pindah ruko dan melaksanakan pesta perkawinan, tetapi juga membeli mobil baru dan membuat kapal. Tidak hanya masyarakat biasa yang menggunakan pedoman hari 
baik dan hari buruk, tetapi juga para profesional, dosen, cendekiawan pun juga melakukan hal yang sama. Semua kegiatan itu dimulai dengan melihat kualitas waktu dalam sehari, apakah waktu itu baik atau kah tidak untuk memulai sebuah aktivitas. Karena adanya kualitas waktu yang baik dan yang tidak, masyarakat Bugis menyebutnya dengan istilah hari baik dan hari buruk.

Hari baik adalah hari yang di dalamnya terdapat kualitas waktu yang baik untuk memulai melakukan sebuah aktivitas, sementara hari buruk adalah hari yang di dalamnya terdapat kualitas waktu yang buruk untuk memulai melakukan sebuah aktivitas. Ibu Nia, misalnya, ketika hendak menempati ruko baru pada hari Ahad, 27 Juni 2017 pukul. 16.00 WITA harus dimajukan waktunya pada pukul 06.00 WITA karena pukul 06.00 WITA dianggap sebagai waktu dengan kualitas terbaik menurut perhitungan orang tuanya (Gunawan, 2014). Hal serupa juga terjadi pada kasus pernikahan Ibu Salma yang hendak menikahkan putrinya Nalia, pada Sabtu, pukul 10.00 WITA harus diundurkan pada keesokan harinya karena hari Ahad pukul 10.00 WITA dianggap sebagai hari baik menurut perhitungan waktu orang tuanya. Jika ibu Salma tidak melaksanakan pernikahan anaknya pada hari Ahad sebagai hari baik, pernikahan anaknya dipastikan batal dan dicarikan waktu lain di bulan berikutnya. Hal ini karena hari Sabtu merupakan hari nakkaseng "hari nahas" menurut orang tua ibu Salma. Karena tidak mau berselisih paham dan menakzimkan orang tuanya, ibu Salma pun menyetujui permintaan orang tuanya.

Fenomena budaya di atas menjelaskan betapa pentingnya penentuan hari baik dan buruk bagi masyarakat Bugis. Penentuan waktu yang baik dalam sebuah hari memiliki pedoman tersendiri. Dengan mengikuti pedoman, mereka yakin bahwa apa yang mereka lakukan dapat berjalan dengan baik, sesuai rencana dan berakhir dengan baik. Mereka yakin bahwa dengan mengikuti pedoman penentuan hari, pernikahan Nalia akan langgeng dan bahtera rumah tangganya dapat berjalan dengan damai, dan renggang konflik. Budaya masyarakat Bugis, hal ini biasa disebut dengan klausa deq na mapella bola'e "rumah tidak akan panas membara". Jika pernikahan itu tetap dilakukan pada waktu yang tidak ditentukan, resikonya adalah masa pernikahannya tidak dapat bertahan lama dan bahtera rumah tangga penuh dengan konflik dan akhirnya berujung pada perceraian. Meskipun demikian, penentuan hari baik dan hari buruk dikembalikan kepada Tuhan. Masyarakat Bugis Kota Kendari seringkali menyebut frase Insya Allah dalam memulai segala aktivitas. Ini juga berarti bahwa dalam penentuan hari baik dan hari nahas, masyarakat Bugis memiliki semangat yang sesuai dengan syariat Islam dan tidak melanggar aturan Allah.

Pedoman penentuan hari baik dan hari buruk itu oleh para tetua adat, tokoh agama atau imam masjid, akademisi, menggunakan simbol-simbol tertentu. Simbol itu berupa lambang-lambang khusus yang dibuat sedemikian rupa sebagai sebuah warisan budaya dari nenek moyang Bugis dahulu. Simbol itu tentu memiliki makna tersendiri dan hanya orang-orang tertentu yang dapat memahaminya. Kamaluddin dkk (2016) menjelaskan bahwa pedoman penentuan hari dan waktu baik itu dimiliki dan diwariskan secara turun temurun. Pedoman itu dapat berbeda antara satu desa dengan desa lainnya. Pedoman itu tidak memiliki pendahuluan seperti sebuah buku, akan tetapi langsung kepada isi naskah tanpa menyebutkan nama pengarangnya. Untuk mempertegas pendapat Kamaluddin, berikut ini disajikan simbol hari baik dan hari buruk yang penulis peroleh dalam penelitian awal. 


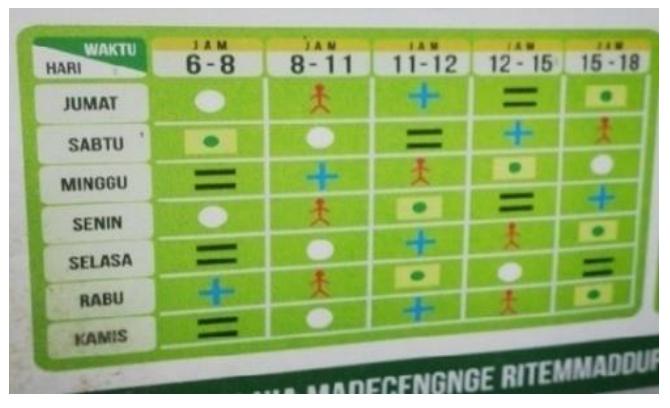

Gambar 1. Simbol Pedoman Hari Baik dan Hari Buruk

Sumber: Rahmatunnair, 2016.

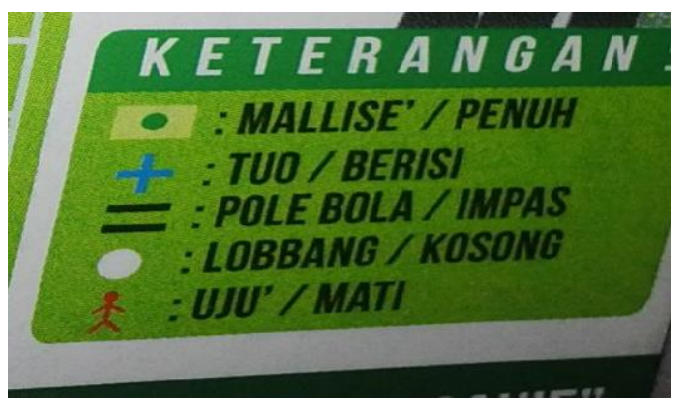

Gambar 2. Makna Pedoman Hari Baik dan Hari Buruk

Sumber: Rahmatunnair, 2016.

Berdasarkan gambar (1-2) diketahui bahwa hari baik dan hari buruk masyarakat Bugis Kendari menggunakan simbol-simbol tertentu. Simbol ini menjelaskan waktu yang baik dan buruk untuk melakukan sebuah aktivitas. Gambar (1) menjelaskan simbol hari baik dan hari buruk, sementara gambar (2) mengungkapkan makna hari baik dan hari buruk.

Penelitian ini menggunakan teori interaksi simbolik George Harbert Mead. Teori ini menjelaskan bahwa komunikasi merupakan hakikat terjadinya interaksi sosial antara individu satu dengan yang lain dan kelompok masyarakat yang satu dengan yang lain (Effendy, 1989). Di dalam sebuah interaksi, pikiran seseorang dapat dipengaruhi baik secara verbal maupun nonverbal. Setiap pesan verbal dan nonverbal dimaknai berdasarkan kesepakatan bersama oleh semua pihak yang terlibat dalam suatu interaksi dan merupakan satu bentuk simbol yang memiliki makna sangat penting. Jadi, dua atau lebih individu cenderung mengeluarkan simbol yang bermakna. Bukan hanya pikiran, perilaku seseorang juga dipengaruhi oleh simbol yang diberikan oleh orang lain (Siregar, 2016). Ini juga berarti bahwa seseorang dapat memberikan makna kepada segala sesuatu yang dapat mengontrol sikap dan tingkah laku mereka. Makna itu berasal dari interaksi antara individu yang satu dengan individu yang lain, atau masyarakat yang satu dengan masyarakat yang lain baik secara verbal maupun nonverbal. Dengan berinteraksi kita memberikan makna kepada kata-kata atau perilaku yang kita lakukan sehingga kita dapat saling memahami antar satu dengan yang lain.

Penelitian hari baik dan hari buruk masyarakat Bugis sudah dikaji beberapa peneliti. Penelitian itu membahas hari baik dan hari buruk dalam perspektif Imam Jafar dan Lontara Pananrang (Munawwar, 2012), sains dan lontara (Yusmar, 2008), pertanian (Kamaluddin dkk, 2016), dan Sunnah Nabawiyyah (Gunawan, 2014; 2015). Hal ini menjelaskan bahwa belum ada satupun penelitian yang membahas hari baik dan hari buruk dalam perspektif interaksionisme simbolik di kalangan masyarakat Bugis Kota Kendari. Oleh karena itu, penelitian ini bertujuan untuk membahas simbol-simbol hari baik dan hari buruk masyarakat Bugis di Kota Kendari.

\section{B. METODE PENELITIAN}

Penelitian ini menggunakan pendekatan deskriptif kualitatif. Data penelitian ini adalah data linguistik yang berupa simbol-simbol waktu dan maknanya secara sosial kebudayaan dalam perspektif masyarakat Bugis Kendari. Koentjaraningrat (2009) mengatakan bahwa bentuk kebudayaan terdiri dari ide, perbuatan dan artefak-artefak. Artefak adalah objek hasil pemikiran manusia, seperti kamus, alat dan simbol-simbol yang dibuat manusia. Simbol hari baik dan hari buruk masyarakat Bugis tentu buatan 
manusia. Data linguistik ini terbatas pada simbol-simbol waktu hari baik dan hari buruk dalam beberapa aktivitas tertentu. Pengumpulan data dilakukan dengan cara wawancara mendalam, observasi, dan dokumentasi (Mahsun, 2005). Teknik pengambilan data dilakukan dengan cara purposive sampling atau theoretical-based sampling (Santosa, 2012).

Wawancara dilakukan terhadap dua puluh informan yang terdiri dari kepala desa, Imam desa, pemuka agama, para orang tua di setiap kecamatan yang memiliki manuskrip pedoman hari baik dan hari buruk selama tiga bulan di kantong-kantong masyarakat Bugis Kota Kendari, yaitu Kecamatan Kendari Kota Lama, Kecamatan Nambo Kelurahan Bungkutoko dan Kecamatan Mandonga. Analisis data dilakukan dengan cara reduksi data, display data dan pengambilan kesimpulan berdasarkan konsep sosial budaya masyarakat setempat (Miles \& Huberman, 1984; Riley, 2007).

\section{HASIL DAN BAHASAN}

Penggunaan simbol hari baik dan hari buruk sangat berkaitan dengan konsep waktu masyakat Bugis. Konsep waktu ini meliputi hari, bulan dan tahun. Perhitungan tahun dalam setahun dihitung berdasarkan waktu panen atau setiap enam bulan. Di dalam sebulan, ada 29 atau 30 hari. Lathief (2005) menjelaskan bahwa hari dalam pandangan masyarakat Bugis dikenal dengan sebutan tertentu, yaitu Masuara, Bisnong, Sirri, Barahamang, and Kala. Namun demikian, karena pengaruh penyebaran agama Islam dan Kristen, masyarakat Bugis mengenal istilah tujuh hari dalam seminggu, yaitu Aha, Senneng, Salasa, Araba, Kammisi, Juma, dan Sattu. Waktu dalam 24 pukul diklasifikasi lagi menjadi 16 sub waktu, yaitu Pajang, Elek Kelek, Pammulang, Enrekesso, Tanggasso, Tanreesso, Araweng, Sarakesso, Petteng, Labbukesso, Sumpang Wenni, Laleng Penni, Tengabenni, Sarawenni, Denniari, Wajeng Pajeng.
Bagi masyarakat Bugis, setiap subwaktu dalam sehari memiliki petunjuk hari mana yang baik atau tidak untuk memulai melakukan setiap aktivitas. Misalnya, hari senin (esso Senneng), Minggu (Aha), Rabu (Araba) dan Jum'at (Juma) adalah hari baik sementara hari Selasa (Salasa) adalah hari buruk atau hari nahas. Salasa dikatakan hari nahas karena memiliki kemiripan huruf dengan kata sala-sala, sisala,lari sala yang dalam budaya Bugis dikenal dengan suara kematian dan keburukan. Setiap sub-waktu dianggap sebagai waktu baik dan waktu buruk dalam sehari. Untuk mengetahui hal tersebut, masyarakat Bugis memiliki pedoman tersendiri yang terdiri dari simbol-simbol. Berdasarkan penelitian, ada 11 macam simbol hari baik dan hari buruk yang ditemukan di Kota Kendari, yaitu (1) simbol tulisan Arab, (2) simbol Matematika, (3) simbol tulisan tangan, (4) simbol lontara Bugis, (5) simbol lontara Bugis dan gambar, (6) simbol aksara Soewandi, (7) simbol hewan, (8) simbol bintang, (9) simbol bendera, (10) simbol H. Daud, (11) simbol Hj. Nursia.

\section{Simbol Tulisan Arab}

Simbol tulisan Arab adalah simbol yang menggunakan tulisan Arab dalam manuskrip pedoman hari baik dan hari buruk. Manuskrip ini diperoleh dari seorang pengusaha Kota Kendari, Ibu Eni. Manuskrip ini disebut dengan simbol tulisan Arab karena tulisan simbolnya menggunakan bahasa Arab. Berdasarkan wawancara, Ibu Eni mengatakan bahwa naskah ini merupakan warisan yang diperoleh dari almarhum KH. Abdul Hafid sebelum wafatnya. KH. Abdul Hafid merupakan seorang ulama Bugis dari Bungkutoko yang belajar agama langsung dari Guruttta almarhum KH. Abdurrahman Ambo Dalle, seorang ulama besar dari Sulawesi Selatan yang juga belajar agama lama di Mekah.

Naskah ini memiliki 7 (tujuh) istilah tertentu dalam bahasa Arab yang digunakan untuk menyatakan hari baik dan 
hari buruk, yaitu musțār, marīḥ̄a, syamsi, șahrīhi, aturīd, qamar, dan zuhal. Pemberian nama ini tentu memiliki makna tertentu. Ketika dikonfirmasi mengenai makna leksikal nama-nama itu, dia pun mengatakan ketidaktahuannya. Namun demikian, secara kontekstual, nama-nama tersebut mempunyai makna jika dihubungkan dengan baik atau buruknya suatu hari. Mustār bermakna mujur atau beruntung. Marīhā bermakna kecil pun buruk, apalagi besar, lebih-lebih buruknya. Syamsi bermakna baik waktunya. șahrīhi bermakna baik waktunya. Aturīd bermakna adakalanya baik dan seringkali juga buruk, kecuali kebaikan yang ditentukan waktunya pada hari Rabu pukul 6. Qamar bermakna adakalanya baik dan adakalanya buruk kecuali kebaikan yang dlakukan pada hari Senin. Zuhal bermakna tidak ada baiknya, kecilnya pun buruk, lebih-lebih besarnya.

Jika dianalisis, terdapat sembilan (9) pola pedoman hari baik dan hari buruk di dalam naskah ini. Hal ini karena ada dua kata yang merujuk kepada hari baik dan sekaligus hari buruk, yaitu aturīd dan qamar. Aturīd merujuk kepada hari baik dan hari buruk dengan pengecualian hari Rabu pukul 06.00 pagi, sementara qamar merujuk pada hari baik dan hari buruk dengan pengecualian hari Senin. Empat (4) istilah lainnya merujuk kepada hari buruk, yaitu marīha $\bar{a}$, zuhal, aturìd, dan qamar, sementara lima (5) istilah merujuk kepada hari baik, yaitu mustār, syamsi, șahrīhi, Aturìd dan qamar. Pedoman hari baik dan hari buruk pada naskah ini dimulai pada hari Sabtu dan diakhiri pada hari Jumat. Semua hari yang ada di dalam naskah menggunakan tulisan Arab, yaitu al-sabt berarti Sabtu, al-ahad berarti Ahad, alisnaini berarti Senin, al-sulasa berarti Selasa, al-arbia' $\bar{a}$ berarti Rabu, alkhamis berarti kamis, dan al-jum'ah berarti Jumat. Setiap hari diklasifikasi menjadi dua bagian, siang dan malam. Siang dimulai pada pukul 06.00 dan diakhiri pukul 17.00. Hal yang sama juga terjadi pada waktu malam. Dimulai pada pukul 18.00 dan diakhiri pukul 05.00. Ini berarti bahwa ada 24 pukul waktu yang disediakan untuk penggunaan hari baik dan hari buruk. Berikut ini akan ditampilkan pedoman waktu setiap hari mulai hari Sabtu hingga Jumat.

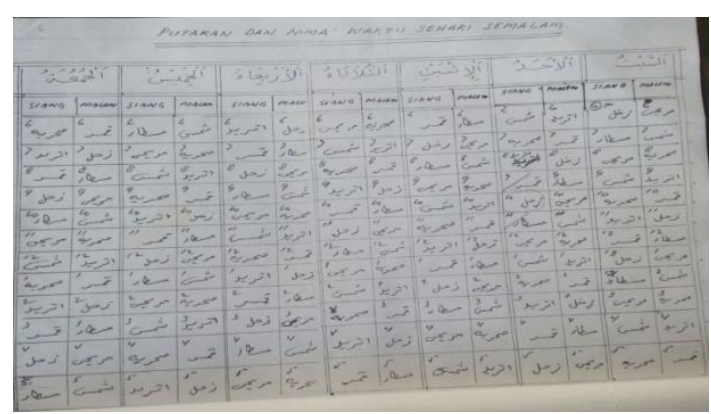

Gambar 3. Pedoman Hari Baik dan Hari Buruk Simbol Tulisan Arab Sumber: Eni, 2017.

Gambar (3) menunjukkan bahwa terdapat waktu baik dan tidak dalam waktu 24 pukul mulai Sabtu hingga Jumat. Berdasarkan wawancara dengan pimpinan pondok pesantren Taḥ̂īz, Baitu al-qur'ān, diketahui bahwa ketika hendak menikahkan putrinya, Ibu Eni menggunakan pedoman hari baik dan hari buruk karena dianggap sebagai sebuah sennu-sennuang. Sennusennuang adalah sebuah rasa optimisme dalam hati bahwa aktivitas ini akan berjalan dengan lancar.

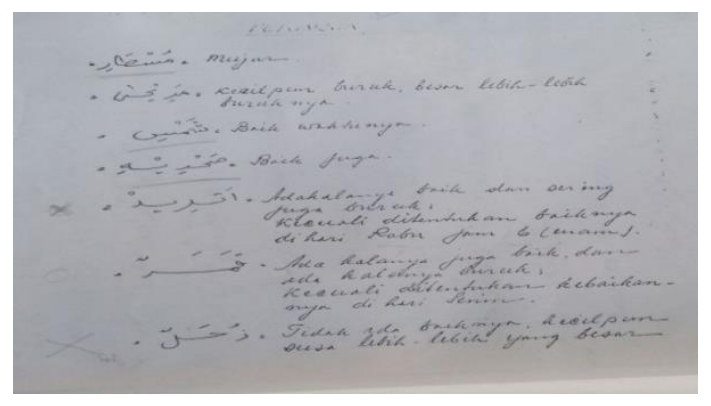

Gambar 4. Makna Simbol Hari baik dan Hari Buruk Simbol Tulisan Arab Sumber: Eni, 2017.

Selain penentuan waktu berdasarkan pukul dan hari, ada juga penentuan waktu berdasarkan bulan. Bulan yang digunakan adalah bulan Qamariyah, yaitu Muḥarram, 
Safar, Rabì'u al-Awwal, Rabì' al-Ākhīr, Jumād al-Awwal, Jumād al-Ākhir, Rajāb, Sya'bān, Ramaḍān, Syawwāl, Zulqā'idah, dan Zulhijjah. Hari buruk atau disebut juga hari nahas juga terdapat pada tanggal tertentu setiap bulan, ketika munculnya bulan dan munculnya bulan yang bertolak belakang. Hari buruk pada bulan nahas jatuh pada tanggal 3 Rabī'u al-Awwal, 5 Rabī' al-Ākhìr, 13 Jumād al-Awwal, 16 Jumād al-Ākhir, 21 Rajāb, 24 Ramaḍān, dan 25 Syawwāl. Selain itu, setiap hari Rabu pada akhir bulan juga dianggap sebagai hari buruk. Adapun munculnya bulan yang bertolak belakang juga dianggap sebagai hari nahas. Hari nahas itu jatuh pada hari Rabu tanggal 2, 12, dan 22, Selasa 3, 13, dan 23, Senin tanggal 4, 14, dan 24, Ahad tanggal 5, 15, dan 25, Sabtu 6, 16, 26, Jumat 7, 17, dan 27, Kamis tanggal 8,18 , dan 28. Hal ini dapat dilihat pada keterangan berikut ini.

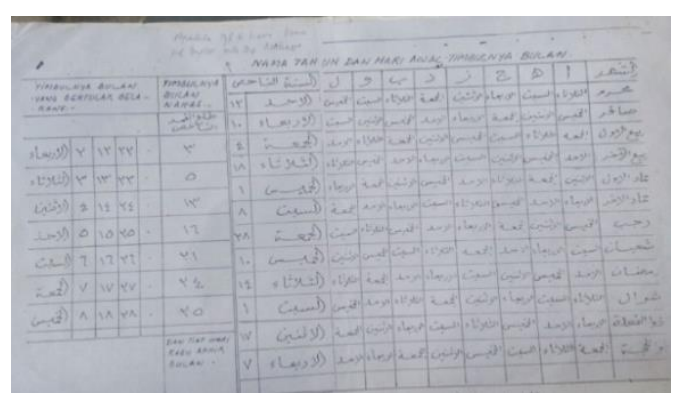

Gambar 5. Pedoman Hari Baik dan Hari Buruk Berdasarkan Hitungan Bulan dengan Simbol Tulisan Arab

Sumber: Eni, 2017.

Senada dengan manuskrip pada gambar (3-5), manuskrip pedoman hari baik dan hari buruk pada gambar (6) merupakan manuskrip yang sama dengan manuskrip sebelumnya. Hanya saja, manuskrip pada gambar (3-5) menggunakan tulisan Arab dan manuskrip pada gambar (6) menggunakan bahasa Indonesia. Perbedaannya adalah naskah ditemukan pada orang yang berbeda.

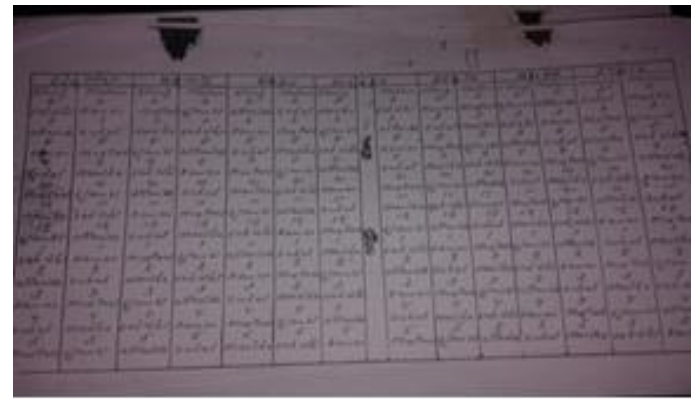

Gambar 6. Pedoman Hari Baik dan Hari Buruk Versi Simbol Tulisan Indonesia Sumber: Eni, 2017.

\section{Simbol Matematika}

Simbol matematika adalah simbol pedoman hari baik dan hari buruk yang menggunakan simbol matematika, seperti simbol tambah (+), lingkaran (o), dan sebagainya. Simbol ini ditemukan di rumah imam masjid Kelurahan Bungkutoko, Ambo Sakka. Berdasarkan wawancara yang dilakukan tentang mengapa pedoman hari baik dan hari buruk berbentuk simbol matematika, dia hanya mengatakan bahwa dia juga mewarisi pedoman itu secara turun temurun dari orang tuanya. Dia tidak mengetahui secara pasti mengapa manuskrip pedomannya menggunakan simbol demikian. Hal ini karena ada beberapa bentuk pedoman itu menggunakan simbol matematika. Dia pun melanjutkan bahwa, "Orang tua saya senantiasa memberikan arahan agar dalam memulai suatu pekerjaan haruslah disertai dengan niat baik dan senantiasa mengikuti pedoman waktu hari baik dan hari buruk. Apa saja aktivitasnya terutama yang berkaitan dengan pesta pernikahan, pindah rumah, dan pergi melaut. Dengan mengikuti pedoman tersebut, kita dapat memperoleh keselamatan dan kebahagian."

Naskah ini menggunakan bahasa Bugis latin. Di dalam naskah, terdapat tulisan pedoman atau petunjuk bilang wettu ri lalenna ta siessoe, iya engka ri poji, ri seseta (pedoman waktu dalam sehari yang engkau sukai). 


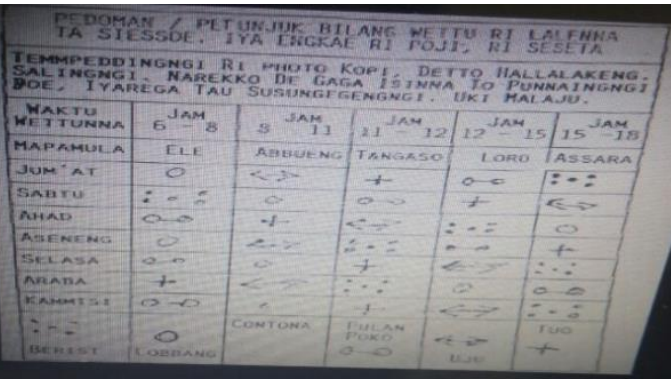

Gambar 7. Pedoman Hari Baik dan Hari Buruk (Simbol Matematika)

Sumber: Ambo Sakka, 2017.

Naskah pada gambar (7) ini memuat beberapa informasi. Informasi pertama yang terdapat pada kolom pertama memuat peringatan bagi pembaca. Dikatakan bahwa, "tempeddingngi ri photo kopi detto hallalakeng salingngi narekko de gaga isinna to punnaingngi boe, iyarega tau susungengngi uki malaju (tidak diperbolehkan salin dan tidak dihalalkan menulis ulang jika tidak ada izin dari orang yang memiliki buku ini atau orang yang menuliskan tulisan Bugis melayu). Kolom kedua dari atas memuat 6 jalur. Jalur pertama dari kiri ke kanan memuat masalah waktu (wettunna) memulai sebuah aktivitas. Waktu itu dimulai hari Jumat (juma), Sabtu (sattu), Ahad (aha), Senin (asseneng), Selasa (salasa), Rabu (araba), dan Kamis (kammisi). Waktu memulai (mappammula) aktivitas dibagi menjadi mapamula, ele, abueng, tangaso, loro, dan assara. Ele dimulai pukul 06.00-08.00. Abueng pukul 08.00-11.00. Tangaso dimulai pukul 11.00-12.00. Loro dimulai pukul 12.00-15.00. Assara dimulai pukul 15.00-18.00.

Adapun simbol hari baik dan hari buruk yang digunakan adalah simbol matematika yang menggunakan huruf Bugis latin. Simbol dadu angka 5 bermakna berisi (berkualitas). Angka kosong (0) berarti lobbang (lubang). Simbol anak panah dengan kedua ujung menggunakan angka 0 berarti pulan poko (Impas). Simbol anak panah dengan kedua ujung tapukul bermakna uju (kematian). Simbol tambah menandakan tuo (kehidupan). Waktu yang baik untuk memulai suatu aktivitas menurut pedoman waktu ini adalah waktu berisi dan tuo karena merujuk pada makna berkualitas dan kehidupan. Ini berarti bahwa semua aktivitas yang dimulai pada waktu ini akan diberi kehidupan, keselamatan, kesejahteraan dan keberkahan. Di sisi lain, waktu yang dianggap buruk dalam memulai sebuah aktivitas adalah uju dan lobbang karena bermakna kematian dan lubang. Ini berarti bahwa apapun aktivitas yang dimulai pada waktu ini berujung pada ketidakselamatan, ketidakberkahan dan tidak baik hasilnya. Sementara itu, pulan poko hanya merujuk kepada sebuah makna sunnah atau diperbolehkan melakukan sebuah aktivitas karena terkadang mengandung kebaikan dan terkadang pula mengandung keburukan.

Hal ini kemudian dipertegas lagi dalam sub-waktu dalam sehari. Misalnya, untuk memulai sebuah aktivitas pada hari Jum'at bagus dilakukan pada pukul 11.00-12.00 karena merujuk pada kata tou dan pukul 15.00-18.00 merujuk pada kata berisi. Sementara itu, pukul 08.0010.00 dan pukul 12.00-15.00 tidaklah dianjurkan sebab merujuk pada kata lobbang dan uju. Hal ini tentu dapat dimengerti jika pukul 11.00-12.00 dikatakan sebagai waktu berkualitas karena memang waktu itu adalah waktu untuk menunaikan solat Jum'at. Siapapun yang menunaikan solat Jum'at berarti akan mendapatkan keberkahan, keselamatan dan ketenangan hidup.

\section{Simbol Tulisan Tangan}

Simbol tulisan tangan adalah simbol pedoman hari baik dan hari 
buruk yang menggunakan tulisan tangan. Dikatakan demikian, karena simbolnya menggunakan tulisan tangan, seperti simbol orang, simbol sama dengan (=), dan sebagainya. Pemilihan waktu dilakukan berdasarkan pedoman simbol ini. Ketika ada kegiatan peletakan batu pertama untuk pembangunan masjid Nur Ikhlas di Tunggala, dalam wawancara yang penulis lakukan, Amir Hudo melakukannya pada pukul 06.00 WITA di hari Sabtu karena menunjukkan makna berisi dengan simbol bendera. Dia berharap bahwa suatu saat nanti ketika sudah selesai dibangun, masjid ini akan dipenuhi banyak orang untuk melakukan salat lima waktu dan selain itu, masjid ini juga dapat dipenuhi dengan berbagai kegiatan keagamaan sehingga penuh dengan keberkahan. Pedoman simbol ini diperoleh secara turun temurun dari orang tuanya. Akan tetapi karena manuskrip aslinya sudah lusuh, dia pun menuliskannya dalam sebuah tulisan tangan.

Simbol yang terdapat dalam naskah ini adalah simbol orang, sama dengan (=), bundaran (0), bendera kosong, dan tambah (+). Simbol orang bermakna mayat, simbol bundaran bermakna kosong, simbol bendera kosong bermakna berisi, simbol sama dengan bermakna pulih, dan simbol tambah bermakna umur panjang. Hari itu dikatakan baik jika simbolnya bermakna berisi dan umur panjang. Sementara hari dikatakan buruk jika simbolnya bermakna mayat, kosong, dan pulih. Pulih ini merupakan bahasa Bugis yang diserap langsung ke bahasa Indonesia dan bermakna sama dengan. Itu berarti bahwa hari itu bisa pertanda baik dan bisa juga pertanda buruk. Berikut ini adalah gambar pedoman hari baik dan hari buruk simbol tulisan tangan

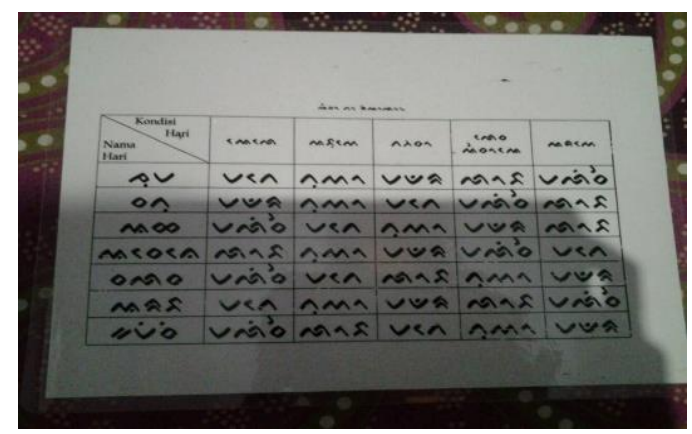

Gambar 8. Pedoman Hari Baik dan Hari Buruk (Simbol Tulisan Tangan) Sumber: Amir Hudo, 2017.

\section{Simbol Lontara Bugis}

Simbol lontara Bugis adalah simbol pedoman hari baik dan hari buruk yang menggunakan huruf aksara Bugis yang disebut lontara. Simbol ini menggunakan aksaran lontara yang berjumlah 23, yaitu ka, ga, nga, ngngka, pa, ba, ma, mpa, ca, ja, nya, nca, ta, da, na, nra, ya, ra, la, wa, sa, a, ha. Hal ini dapat dilihat pada gambar (9) berikut.

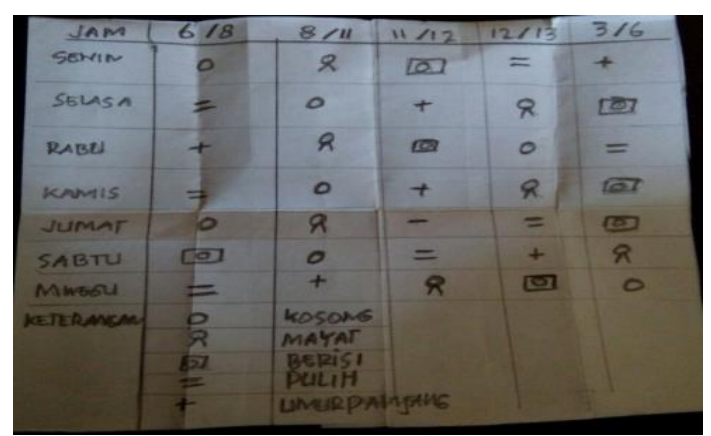

Gambar 9. Pedoman Hari Baik dan Hari Buruk (Simbol Lontara Bugis) Sumber: Syamsuddin, 2017.

Gambar (9) ini menjelaskan nama dan kondisi hari. Jalur pertama secara vertikal diisi oleh nama hari, seperti hari juma, satu, aha, eseneng, salasa, araba, dan kammisi, sementara secara horizontal diisi oleh kondisi hari atau waktu. Waktu yang dimaksud adalah ele, abueng, tanggasso, leso essoe, dan araweng. Waktu ele dimulai pada pukul 06.00-08.00. Abueng dimulai pada pukul 08.00-11.00, tanggaso dimulai pada pukul 11.00-12.00. Lesa essoe dimulai pada pukul 12.00- 
15.00, dan araweng dimulai pada pukul 15.00-18.00. Setiap kondisi memiliki makna masing-masing, yaitu mate, tuwo, maddara, lobbang, dan mallise. Mate bermakna mati. Tuwo bermakna hidup. Mallise bermakna berisi. Maddara bermakna berdarah. Lobbang bermakna pulang pokok. Hari itu dianggap baik waktunya jika menunjukkan tuwo dan mallise, sementara hari dianggap buruk waktunya jika menunjukkan mate dan maddara. Sementara lobbang menunjukkan waktu yang terkadang baik dan terkadang pula buruk.

Sebagai contoh, hari Senin pukul 06.00-08.00 menunjukkan waktu lobbang, 08.00-11.00 menunjukkan waktu tuwo, 11.00-12.00 menunjukkan waktu maddara, 12.00-15.00 menunjukkan waktu mallise, dan 15.00-18.00 menunjukkan waktu mate. Ini berarti bahwa aktivitas pergi melaut, pindah rumah atau pernikahan anak, jika dilaksanakan pada hari Senin, maka bagus dilakukan pada pukul 08.00-11.00 dan 12.00-15.00. hal ini karena kedua waktu ini menunjukkan waktu tuwo dan mallise yang bermakna kehidupan dan berkualitas waktunya.

\section{Simbol Lontara Bugis dan Gambar}

Yang dimaksud simbol lontara Bugis dan gambar adalah simbol pedoman hari baik dan hari buruk yang menggunakan gabungan lontara Bugis dan gambar. Simbol ini senada dengan simbol lontara Bugis dalam hal klasifikasi kualitas hari menjadi 5, ele, abueng, tengga esso, lohoro, dan assara, pembagian waktu dalam seminggu, yaitu aha, esseneng, salasa, araba, kammisi, juma, dan sattu. Hanya saja perbedaannya terletak pada penggunaan nama yang maknanya juga sama dengan simbol lontara Bugis. Di antara namanya adalah mallise, lobba, makerre, uju amateng, dan pole bola. Mallise dan lobba merujuk pada waktu yang bagus digunakan untuk memulai aktivitas, makerre dan uju amateng merujuk pada waktu yang buruk digunakan untuk memulai aktivitas, dan pole bola adalah waktu yang terkadang baik dan terkadang juga buruk untuk memulai sebuah aktivitas. Waktu mallise disimbolkan dengan gambar dadu angka lima dan bermakna berisi. Waktu lobba disimbolkan dengan gambar persegi empat dan bermakna beruntung. Waktu makerre disimbolkan dengan gambar tulang yang membentuk huruf $\mathrm{x}$ dan bermakna sulit, uju amateng disimbolkan dengan gambar garis panjang hitam dan bermakna kematian, sementara pole bola ditandai dengan gambar huruf $x$. Hal ini dapat dilihat pada data berikut ini.

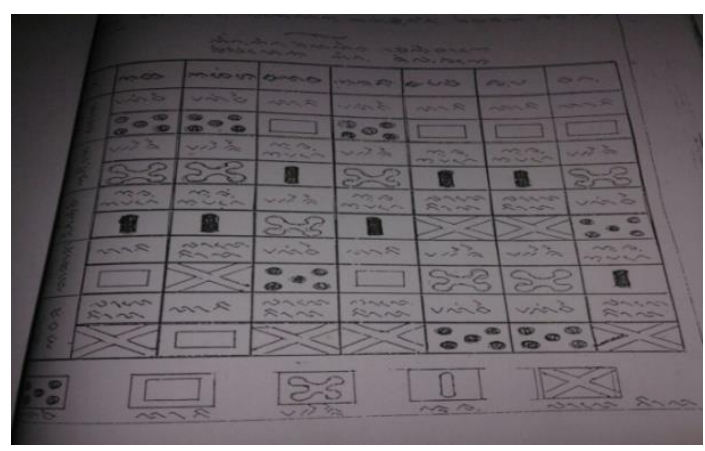

Gambar 10. Pedoman Hari Baik dan Hari Buruk (Simbol Lontara dan Gambar) Sumber: Syamsuddin, 2017.

\section{Simbol Ejaan Soewandi}

Simbol ejaan Soewandi yang dimaksud adalah simbol pedoman hari baik dan hari buruk yang menggunakan ejaan Soewandi. Simbol ini dikatakan simbol ejaan Soewandi karena menggunakan ejaan Soewandi. Ejaan ini dapat diidentifikasi karena menggunakan $\mid d j /$ untuk fonem $/ j /, \mid j /$ untuk fonem $/ y /$, /nj/ untuk fonem /ny/, /sj/ untuk fonem /sy/, $/ b /$ untuk fonem $/ p /$, le/ untuk fonem $/ \mathrm{a}$. Fonem ini digunakan oleh masyarakat bangsa Indonesia sejak 1947 hingga 1972. Sebagai contoh, naskah ini menggunakan fonem /dj/ pada kata Djumat untuk kata Jum'at. Harinja untuk kata harinya. Bahaja untuk kata bahaya. Hidub untuk kata hidup. Kemis untuk kata kamis. Rebo untuk kata rabu. Hal ini dipertegas dengan tanggal penulisan naskah pada bagian bawah kanan, 14 Mei 1965. 
Pedoman hari baik dan hari buruk dalam naskah ini dikhususkan untuk orang yang melakukan perjalanan. Pedoman ini hanya menggunakan nama hari dan waktu untuk bepergian. Sementara simbol yang digunakan itu juga ada lima. Simbol lingkaran yang mempunyai titik di tengah bermakna kubur. Simbol orang bermakna beruntung. Simbol X bermakna bahaya, simbol dadu angka 5 bermakna isi, simbol huruf I besar bermakna hidup. Simbol orang, angka 5, dan huruf I menandakan waktu yang baik untuk bepergian, sementara simbol huruf $\mathrm{X}$ dan lingkaran yang di tengahnya ada titik menunjukkan waktu yang tidak baik untuk melakukan perjalanan atau bepergian. Hal ini dapat dilihat pada gambar (11) berikut ini.

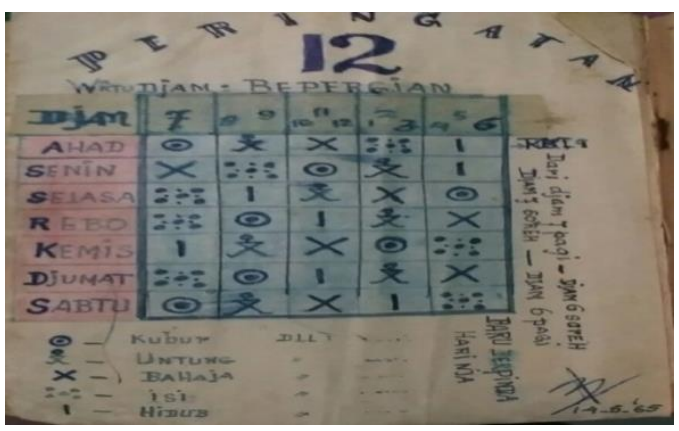

Gambar 11. Pedoman Hari Baik dan Hari Buruk (Simbol Ejaan Soewandi) Sumber: Muhammad Iman, 2017.

\section{Simbol Hewan}

Berdasarkan wawancara dengan salah seorang Imam desa di Kecamatan Kendari Kota Lama, pedoman hari baik dan hari buruk juga menggunakan simbol hewan. Berbeda dengan simbol lainnya yang menggunakan waktu hanya dalam seminggu mulai dari Jumat, atau Sabtu, atau Ahad, simbol ini menggunakan tanggal mulai dari tanggal 1 hingga tanggal 30 dalam setiap bulan, mulai bulan Januari hingga Desember. Dengan demikian, tanggal 1 hingga tanggal 30 menggunakan simbol hewan yang berbeda. Ada hewan yang digunakan untuk menyatakan hari baik dan ada hewan tertentu yang digunakan untuk menyatakan hari buruk. Penggunaan simbol hewan ini juga diberikan penafsiran dan pembandingan dengan menyebut namanama Nabi yang dapat bermakna baik.

H. Daud dalam wawancaranya mengatakan bahwa ada hewan tertentu yang diasosiasikan sebagai hari baik dan hari buruk, dan ada pula hewan tertentu yang diasosiasikan baik pada hari baik maupun hari buruk. Hewan yang diasosiasikan dengan hari baik berjumlah sebelas (11). Hewan yang diasosiasikan dengan hari buruk berjumlah tiga (3). Hewan yang diasosiasikan dengan hari baik dan hari buruk berjumlah delapan (8). Hewan yang diasosiasikan dengan hari baik adalah (1) anynyarang (kuda) pada tanggal 1, tedong (kerbau) pada tanggal 6 , saping (sapi) jatuh pada tanggal 8 , bembei (kambing) pada tanggal 11, gajai (gajah) pada tanggal 12, sarigala (serigala) pada tanggal 14, lanceng (monyet) pada tanggal 19, ula (ular) pada tanggal 20, ancale (belalang) pada tanggal 23, dongi-dongi (burung pipit) pada tanggal 29, manu (ayam) pada tanggal 30, dan macang (macan). Hal ini senada dengan penjelasan dalam naskah pananrang sebagaimana berikut.

\section{Data 1}

"Esso anynyarang asenna, ana-ana jaji malampe sunge'i pegaui passurong Puang, matturu'i ripajajianna, masempo dalle' $i$ nasaba esso ripancajinna Nabi Adam. Agiagi pura tempeddingngi riappammulang"

"Hari Kuda namanya; bayi yang lahir panjang umur dan taat perintah Allah, menurut pada orang tua, murah rezki karena hari kelahiran Nabi Adam as. Apapun yang telah selesai tidak boleh dimulai lagi".

\section{Data 2}

"Esso tedong asenna,makessing тиа rilaoang mabela, runtu'ki alabang, makessing muto rikawingang, najajiang ana tanra maccai mabbicara toriolo, pugau'i passurong Puang, tapi kasi-asiwi, makessingngi riangelliang tedong (saping) iyarega olo-kolo mawijai, makessingngi 
riakkabbureng wakke nasaba teai lobbang wakke'na ritu, makessing muto riappanorang bine (ase)."

"Hari kerbau namanya. Baik untuk melakukan perjalanan jauh, terkadang mendapatkan musibah, bagus untuk mengadakan pernikahan, jika mempunyai anak, maka ia akan pintar berbicara tentang sejarah, taat kepada Allah, tapi mempunyai keterbatasan harta, bagus untuk membeli kerbau atau hewan ternak lainnya untuk dipelihara, bagus jika untuk menanam benih."

\section{Data 3}

"Esso sapingngi asenna, ana-ana jaji malomo patulungngi ripadanna tau, masempo dalle' $i, \quad$ madecengngi rikawingeng nenniya riappatettongeng bola nasaba mattiro camming asenna, madeceng muto rilaoang sompe (tegatega), madeceng riappammulang balubalu."

"Hari sapi namanya. Jika melahirkan anak, dia akan mudah membantu banyak orang, murah rezeki, bagus untuk mengadakan pernikahan, mendirikan rumah, bagus juga untuk bepergian dan memulai berdagang."

\section{Data 4}

"Esso bembe'i asenna, makessingngi nasaba iyanaritu nariputtama Nabi Adam ri surugae, najajiangngi ana' turu', maupe' $i$, malampe sunge'i napugau'i passuroangna Puang Allah Ta'ala."

"Hari kambing namanya. Hari ini bagus karena Nabi Adam masuk surga pada hari ini. Jika melahirkan anak, ia akan menjadi anak yang beruntung. Panjang umur. Taat kepada Allah."

\section{Data 5}

"Esso gajai asenna, temmagagai tau laloe, toriwelaiye, tau ripoleiye nasaba iya najajiang Nabi Muhammad SAW, najajiang ana maupe'i pogau'i passuroang, madeceng riappanorang bine, agi-aginna madecengngi nasaba barakka'na Nabitta Muhammad saw."

"Hari Gajah namanya. Tidak masalah orang yang ditinggalkan, orang yang datang karena itu hari lahir nabi Muhammad. jika melahirkan anak, ia akan menjadi anak yang beruntung, taat agama. Baik untuk menurunkan benih. Apa saja yang dilakukan bisa berdampak baik karena berkah nabi Muhammad."

\section{Data 6}

"Esso serigala asenna, sininna jamajamang madecengnge salama'I ripugau, makessingngi rilaoang maтmusu, dangkang, sibawa rikawingeng nasaba iyanaritu narijajiang Nabi Sulaiman, najajiangngi ana sugi' $i$.”

"Hari serigala namanya. Semua pekerjaan bagus dilakukan. Baik untuk pergi berperang. Bisnis dan juga pernikahan karena hari itu adalah hari dilahirkan nabi Sulaeman. Hari dilahirkan anak kaya."

\section{Data 7}

"Esso lancengngi asenna, najajiang ana pogau'i passurongna Puang Allah Ta'ala, malomoi sugi, malomo atiwi ripadanna tau sibawa ripajajianna, esso najajiangnge Nabi Yakub, makessingngi rilaoang dangkang."

"Hari monyet namanya. Ketika melahirkan anak, ia akan taat kepada Allah. Mudah untuk menjadi orang kaya. Murah hati kepada sesama manusia. Hari diciptakan nabi Yakub. Bagus untuk pergi berdagang."

\section{Data 8}

'Esso ula' asenna, makessing ladde rilaoang madduta, najajiangngi ana teyai tessugi, esso najajiangnge Nabi Ismail"

"Hari ular namanya. Bagus untuk pergi meminang. Jika melahirkan anak, pasti jadi orang kaya. Hari diciptakan nabi Ismail." 


\section{Data 9}

"Esso incale asenna, makessingngi riabbottingeng, sawei mawase'ki, riangelliang appakeng temmaradde'i ridi, tapi makessingngi riangelliang balu-balu, magatti'i tarala namakessing sarona."

"Hari belalang namanya. Bagus untuk melakukan pesta pernikahan. Bagus juga untuk membeli dagangan karena cepat laku dan banyak untungnya."

\section{Data 10}

"Esso sikadongngi asenna, madeceng riallantikeng tomapparenta nasaba mattuppu batui batena mapparenta, madeceng to riangelliang balu-balu nasaba magatti' $i$ taralla, naekiya maja' $i$ riangelliang appakeng nasaba nalai pelolang atau tabbei, madecetto rilaoang sompe, riattanengeng, agi-agi jamajamang madeceng manengi ritu."

Hari burung namanya. Bagus untuk melakukan pelantikan pejabat karena pasti akan mendapatkan banyak halangan dalam pemerintahannya. Bagus untuk membeli barang dagangan karena akan cepat laku. Tapi jelek untuk membeli perhiasan karena dapat dicuri atau tercecer hilang. Bagus untuk melakukan perjalanan, menanam benih, semua pekerjaan yang dilakukan akan menghasilkan hasil yang bagus.

\section{Data 11}

"Esso manu asenna, makessingi rilaoang dangkang nasaba salama'I iyatonaro naripaturung dalle'e risininna ripancajie, makessingngi riellau doangeng rimunri sempajang assara', iyatonae esso aminang macoa, appettung bicaratoi sininna pananrangnge rilangi'e, ana jaji"

Hari ayam namanya. Bagus untuk berdagang karena akan mendapatkan keselamatan. Rezeki akan datang menghampiri. Bagus untuk berdoa setelah solat ashar. Ini juga hari yang tertua.

Adapun hari buruk disimbolkan dengan binatang Macang (macan) pada tanggal 1,
Kalapung (kura-kura) pada tanggal 5, dan singa (singa) pada tanggal 13. Hal ini sejalan dengan dokumen naskah pananrang sebagaimana berikut ini.

\section{Data 12}

"Esso macang asenna, nakase'i nasaba esso najajiangnge Kabil ana'na Adam. Ana-ana jaji madorakai ripajajianna, maja'i riappabbottingeng, majai riattanengeng, rilaoangngi mabelanakennai sukkara, iyanaro naripassu' Adam-Hawa pole ri surugana Puang Allah Ta'ala."

"Hari Macan namanya. Nahas sebab hari kelahirannya Kabil putra Adam as. Anakanak yang lahir, durhaka pada orang tuanya. Tidak baik untuk pernikahan, tidak baik untuk menanam, tidak baik untuk perjalanan (sebab) mendapatkan kesukaran, adalah (hari) dikeluarkannya Adam- Hawa dari Surga".

\section{Data 13}

"Esso kalapui asenna, najajiangngi ana madorakai ripajajianna, nakase'i denawedding riappanorang bine".

"Hari kura-kura namanya. Jika melahirkan anak, ia akan menjadi anak durhaka, tidak diperbolehkan untuk menurunkan benihbenih untuk menanam".

\section{Data 14}

"Esso singa asenna, nakase'i (maja'i) nasaba esso ritununna api Nabi Ibrahim, ripakkerina Raja Namrud, najajiangngi ana mabbiasai ujangeng, rilaoangngi mabela biasai nakennaki lasa ritengnga laleng atau mateki rilaotta."

"Hari singa namanya. Hari ini buruk karena hari dibakarnya nabi Ibrahim. Jika melahirkan anak, biasanya menjadi gila. Jika bepergian jauh, biasana mendadak jatuh sakit di tengah perjalanan atau meninnggal dalam perjalanan.”

Adapun hari baik dan hari buruk secara sekaligus disimbolkan dengan hewan 
jonga (rusa) pada tanggal 2, meyong (kucing), balawo (tikus) pada tanggal 7, asu (anjing) pada tanggal 9, Nagai (naga) pada tanggal 10, iti (itik) pada tanggal 15, bawi (babi) pada tanggal 16, balipeng (kalajengking) pada tanggal 17. Hal ini sejalan dengan data naskah pananrang sebagaimana berikut ini.

\section{Data 15}

"Esso jonga asenna, najajiangngi ana' pertama, maupe'i namasiga mallakkai, apa iyanaritu naripancaji neneta Hawa. Agi-agi madecengnge wedding mua ripugau, rilaoangngi sompe, runtu'ki alabang, tapi de' nawedding rilaoangngi mammusu."

"Hari Rusa namanya; apabila melahirkan anak, dia akan beruntung (sebab) cepat bersuami. Karena hari diciptakannya nenek kita siti Hawa as. Apapun hal baik dapat dilakukan pada hari ini (seperti) perjalanan jauh/merantau, mendapatkan alabang. Akan tetapi kurang baik berperang."

\section{Data 16}

"Esso meyong asenna, najajiangngi ana baraniwi, makessingngi riappanorang bine, tapi ompo 4-5-6-7-13-15-17 majai riappammulang mattaneng ase nasaba nanrei ule, makessing muto rilaoang mabela, narekko tau kawing pangkagarengngi nadenaullei massarang, narekko riakkalangngi inreng denariullei waja'i."

"Hari kucing namanya. (jika) melahirkan anak, (maka ia akan) berani. Baik untuk menebar bibit. Akan tetapi tanggal 4-5-67-13-15-17 (Bulan hijrah) tidak baik dimulai menanam padi sebab dimakan hama/ulat. Baik untuk pergi jauh/merantau. Jika orang menikah (di hari ini) tidak bisa bercerai. Jika berutang, sulit terbayar."

\section{Data 17}

"Esso balawo asenna, tempeddingngi riakkalang inreng nasaba tenriullei waja' $i$, maja' toi riellauang wae galung nasaba nanrei kare ase ritu, tapi makessingngi riakkebbureng pakkakkasa no' ri salo'e/ri tasi'e, madeceng muto rikawingeng nasaba weddingngi sugi.,"

"Hari tikus namanya. Tidak boleh meminjam karena tidak akan bisa membayar hutang. Tidak bagus untuk mengalirkan air sawah karena bisa dimakan padinya, bagus untuk membuat peralatan untuk berlayar, bagus juga melakukan pernikahan karena bisa menjadi kaya."

\section{Data 18}

"Esso asui asenna, madecengngi riappammulang mattaneng rigalungnge sibawa waena galungnge mappammula malaki' wae galung, mauni sibotolo' muna naripenre riakkeangnge, najajiangngi ana-ana madorakai ripajajianna sibawa ri Puang Allah Ta'ala. Narekko rikawingengngi malomoi massarang iyarega matei masitta makkunraie."

"Hari anjing namanya. Bagus untuk memulai menanam di sawah dan air sawah dapat diawali untuk ambil dari air sawah meskipun hanya sebotol. Jika mempunyai anak, akan menjadi anak yang durhakan atas perintah Allah. Jika menikah, akan mudah bercerai atau istrinya dapat cepat meninggal."

\section{Data 19}

“Esso nagai asenna, maja' $i$ riappammulang mattaneng rigalungnge/ridare'e, makessing tosi rilaloang mangolo riarungnge, makessing riabbottingeng, najajiangngi ana'maupe'i."

"Hari naga namanya. Tidak bagus untuk memulai bersawah atau berkebun. Bagus untuk menghadap kepada para pejabat. Bagus untuk melakukan pernikahan. Jika melahirkan anak, ia akan menjadi anak yang beruntung." 
Data 20

"Esso iti asenna, ana-ana jaji pogau'i passuroang, naniriwi pappesangka, turu'i ripajajianna, riammasei ri padanna tau, macanti'i tappana nasaba najajiangnge Nabi Yusuf, tempeddingngi riappatettongeng bola nasaba teyai nasalai lasa punnana, rilaoangngi sompe nakennaki lasa atau halangeng."

"Hari itik namanya. Anak yang dilahirkan menjadi anak yang taat agama. Berbaik sangka. Taat kepada orang tuanya. Sayang kepada sesama manusia. Tampan mukanya karena hari dilahirkannya nabi Yusuf. Boleh membangun rumah karena pemilik rumahnya tidak akan mendapatkan musibah sakit. Jika bepergian, ia akan mendapatkan musibah atau halangan."

\section{Data 21}

"Esso bawi asenna, nakase'i nasaba esso ribuanna Nabi Yusuf rikalebbongnge ri padaranena, ana-ana jaji ujangengngi, agi-agi maja'i ripugau kecuali mattaneng ikkaju ki', mabbuai, madecengngi riakkabbureng onrong doi' teyai lobbang."

"Hari babi namanya. Hari ini hari nahas karena hari ini adalah hari ketika nabi Yusuf dibuang ke lubang sumur oleh saudara laki-lakinya. Ketika melahirkan anak, ia akan menjadi gila. Apapun buruk dilakukan kecuali menanam sayur. Bagus dibuatkan tempat berkumpul."

\section{Data 22}

"Esso balipeng asenna, nakase'i nasaba esso najajiangnge Nabi Isa, najajiangngi ana macanti'i, iyatonaro naripancaji matanna essoe, salama'i rilaoang mabela atau sompe, narekko jajiang ana napeddiri ati tomatoanna, tapi pogau'i passuroang Puang Allah Ta'ala."

"Hari balipeng namanya. Hari ini hari buruk karena hari diciptakannya nabi Isa. Ketika melahirkan anak, dia akan menjadi anak yang cantik. Hari ini juga hari diciptakan matahari. Baik untuk melakukan bepergian atau perjalanan jauh. Ketika melahirkan anak, ia akan menjadi anak yang menyakitkan hati orang tuanya, tapi taat kepada Allah."

Persoalan mengapa hari baik dan hari buruk disimbolkan dengan hewanhewan tertentu hanya karena semua binatang tersebut menjadi sangat akrab dalam kehidupannya, terutama generasi etnis Bugis masa lampau.

\section{Simbol Bintang}

Sebuah wawancara dengan tetua adat di Kecamatan Abeli menunjukkan bahwa simbol bintang juga digunakan untuk mengetahui bahwa hari baik dan hari buruk. Pedoman itu biasanya digunakan bagi para nelayan yang hendak berlayar mencari ikan. Orang Bugis dapat mengetahui nama-nama bulan yang muncul di langit dengan memperhatikan posisi bintang ketika matahari tenggelam. Posisi bintang di langit diperhatikan sebelum dan selama berlayar dan mencari ikan. Di antara posisi bintang itu adalah bittoeng tanra tellu, bittoeng warongmprong, bittoeng manu 'lai, bittoeng eppang, bittoeng tobalu and bittoeng lamuru.

Ketika bittoeng tanra tellu (bintang tanda tiga) muncul di timur, angin kencang akan datang. Jika bittoeng warongpong (bintang warongpong) muncul di timur, ada banyak ikan di laut. Jika bintang warongpong muncul di atas kepala, angin beliung akan datang. Jika bintang manu lai (bintang ayam jantan) muncul di timur, matahari akan terbit. Jika bittoeng eppang (bintang empat) tampak di bagian selatan ketika matahari terbenam, ikan terbang akan banyak muncul. Jika Bittoeng tobalu (bintang Tobalu) tampak di bagian selatan, dan bintang itu menunjukkan posisi 180 derajat pada musim timur, akan datang angin kencang. Jika bittoeng lamuru (bintang Lamuru) muncul di bagian tenggara, bintang ini menandakan banyaknya jumlah ikan di laut. 


\section{Simbol Bendera}

Simbol bendera adalah simbol pedoman hari baik dan hari buruk yang menggunakan simbol bendera. Dikatakan simbol bendera sebab salah satu simbol di dalam pedoman tersebut menggunakan bendera Brazil, yaitu bendera berwarna kuning dengan titik hijau di tengahnya. Simbol ini diklasifikasikan menjadi 7 hari dan 5 waktu. Dari hari Jumat hingga Kamis. Mengenai pembagian waktu, waktu 06.00-08.00 menunjukan ele, 08.00-11.00 menunjukkan abueng, 11.00-12.00 menunjukkan tengnga esso, 12.00-15.00 menunjukkan loro, dan 15.00-18.00 menunjukan assara. Pedoman ini memiliki 5 simbol, yaitu mallise, tuo, pole bola, lobbang, dan uju. Waktu yang bagus untuk memulai sebuah aktivitas adalah ketika menunjukkan waktu mallise atau tuo karena keduanya menunjukkan waktu baik, sementara lobbang dan uju menunjukkan waktu yang tidak baik. Pole bola terkadang menunjukkan waktu baik dan terkadang pula menunjukkan waktu tidak baik. Hal ini dapat dilihat sebagaimana yang telah dijelaskan pada gambar (1-2).

\section{Simbol H. Daud}

Simbol Hj. Daud adalah simbol pedoman hari baik dan hari buruk yang dinisbatkan kepada pemiliknya, H. Daud. Dia adalah seorang di Imam Masjid di kota lama. Dalam kesehariannya, dia selalu menggunakan pedoman waktu untuk memulai sebuah aktifitas, misalnya ketika pergi melaut, pindah rumah, pesta pernikahan, melakukan perjalanan selalu menggunakan pedoman waktu tersebut. Pedoman waktu sudah digunakan sejak 23 Januari 1956 sebagaimana tertuang dalam manuskrip gambar (12).

Di dalam manuskrip pedoman ini, terdapat 7 hari dan 4 simbol waktu dan maknanya. Simbol bujursangkar bermakna rezeki, simbol tanda tambah berekor bermakna celaka, simbol huruf $\mathrm{X}$ besar bermakna halangan, dan simbol

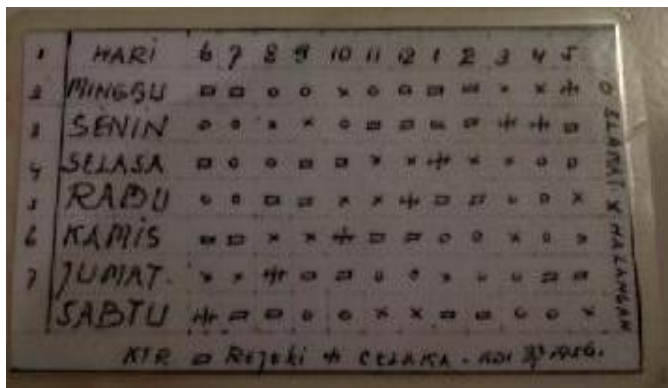

Gambar 12. Pedoman Hari Baik dan Hari Buruk (Simbol Hj. Daud) Sumber: Hj. Daud, 2015.

\section{Simbol Hj. Nursiah}

Simbol Hj. Nursiah adalah simbol pedoman hari baik dan hari buruk yang dinisbatkan kepada pemiliknya. Pedoman ini seringkali digunakan dalam memulai sebuah aktivitas. Wawancara yang penulis lakukan menunjukkan bahwa ketika suami $\mathrm{Hj}$. Nursiah hendak melaut mencari ikan, dia menggunakan pedoman ini. Walhasil, ikan yang diperolehnya melimpah ruah. Lanjut dikatakan bahwa pernah dia pergi melaut saja tanpa memperhatikan waktu baiknya atau hari baiknya, dia pun pulang dengan hasil yang kurang menggembirakan.

Ada 4 simbol yang digunakan dalam pedoman ini. Simbol segiempat bermakna rejeki, tanda silang bermakna halangan, tanda sama dengan silang bermakna sial, dan huruf $\mathrm{O}$ berekor bermakna selamat. Hal ini dapat dilihat pada gambar (13).

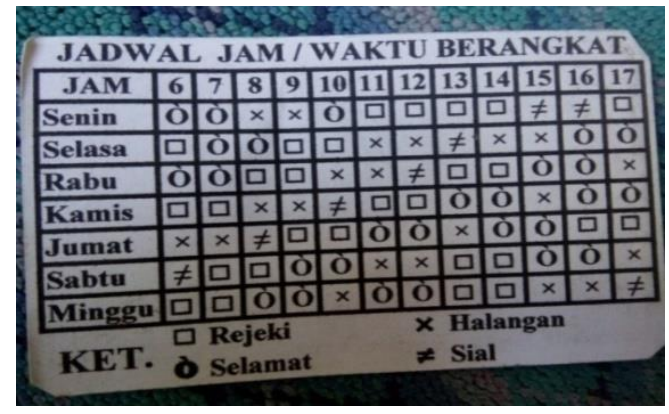

Gambar 13. Pedoman Hari Baik dan Hari Buruk (Simbol Hj. Nursiah) Sumber: Hj. Nursiah, 2015.

angka nol bermakna selamat. 
Berdasarkan penelusuran penulis, pedoman hari baik atau petunjuk waktu mempunyai banyak versi. Versi ini didasarkan pada pengalaman masingmasing para leluhur Bugis sesuai dengan apa yang dirasakan dan dialami. Ketika mengalami sebuah peristiwa yang baik pada suatu waktu dan kejadian tertentu dan kejadian itu terjadi berulang kali, maka seringkali mereka menuliskannya dan mengabadikannya dalam lontara. Dengan demikian, perbedaan pengalaman leluhur Bugis yang satu dengan yang lain menjadi sesuatu yang tidak dapat dihindari. Karena berdasarkan pengalaman pribadi masingmasing itulah mengapa simbol pedoman hari baik dan hari buruk itu ada. Antara satu pedoman dengan pedoman lain tidak ada yang dikatakan paling benar dan tidak ada pula dikatakan paling salah. Semua benar sesuai versi dan pengalaman mereka masing-masing. Salah satu tokoh adat Bugis mengatakan bahwa

"Mengapa Allah menjadikan waktu itu dalam 7 hari itu pasti ada hikmahnya. Allah menjadikan waktu 7 hari karena pada tiap-tiap hari itu, pasti ada faedahnya. Dalam sehari, misalnya hari Senin, aka nada waktu yang bagus untuk memulai melaksanakan suatu kegiatan. Sementara waktu lainnya bukanlah waktu yang buruk. Hanya saja dalam bahasa Bugis, ada disebut dengan malebbi wettue atau waktu yang lebih baik. Itu bukan berarti bahwa ada waktu yang buruk. Semua waktu baik. Hanya ada yang lebih baik dari yang baik untuk memulai melakukan sebuah aktifitas. Senada dengan pandangan di atas, Rasulullah bersabda, barangsiapa yang mencela waktu, maka ia telah mencela Allah. Karena Allah itu adalah waktu."

Pedoman simbol sebelumnya menjelaskan bahwa dalam sehari itu tidak ada yang disebut hari baik dan hari buruk. Yang ada adalah hari dengan kualitas waktu dengan segala konsekuensinya. Dengan demikian, pilihan waktu yang dimaksud adalah waktu dari pagi sampai sore yang diklasifikasi menjadi 5 macam, yaitu ele (pagi), abuang (duha), tengnga esso (tengah hari), loro (siang), assara (sore). Sementara itu, kualitas waktu juga dibagi menjadi 5, yaitu mallise (berisi), mate atau uju (kematian), pola bola (impas), salama (keselamatan), dan lobbang (berlubang). Lima kualitas waktu inilah yang menjadi pemicu sehingga muncul istilah hari baik dan hari buruk. Lima kualitas waktu dalam sehari menunjukkan bahwa meskipun hari itu bagus, namun ada yang sangat bagus, bagus, lebih bagus, cukup bagus dan kurang bagus. Hal yang sama dalam penelitian kuantitatif dikenal dengan sebutan, skala Likert untuk membandingkan sesuatu hal dengan hal lainnya. Perbandingan itu dapat dilihat pada salah satu contoh hari berikut ini.

Hari senin waktu ele, simbol matematika, simbol komputer, simbol lontara, simbol bendera, dan simbol bahasa Arab merujuk pada kualitas waktu lobbang; Simbol bugis dan gambar, simbol bahasa Arab, simbol aksara Suwandi merujuk pada waktu kualitas waktu mallise; simbol $\mathrm{Hj}$ Daud dan simbol $\mathrm{Hj}$ Nursia merujuk pada kualitas waktu salama; simbol aksara Suwandi merujuk pada kualitas waktu uju; sementara simbol bahasa Arab merujuk pada kualitas waktu pole bola . Hari Senin waktu abueng, simbol lontara dan simbol aksara Soewandi merujuk pada kualitas waktu mallise; simbol komputer, simbol bugis dan gambar, simbol H Daud, simbol $\mathrm{Hj}$. Nursia, simbol bendera, dan simbol bahasa arab merujuk pada kualitas waktu uju; sementara simbol matematika merujuk pada kualitas waktu pole bola. Hari Senin waktu tengnga esso, semua simbol merujuk pada kualitas waktu uju kecuali simbol matematika merujuk pada kualitas waktu pole bola. Hari senin waktu loro, simbol lontara, simbol H Daud, dan simbol $\mathrm{Hj}$ Nursia merujuk pada kualitas waktu mallise; simbol bahasa Arab, simbol komputer, simbol aksara Soewandi, dan simbol bendera merujuk pada kualitas 
waktu salama; Simbol bahasa Arab, simbol matematika, simbol komputer, simbol lontara dan gambar, simbol bendera merujuk pada kualitas waktu pole bola. Senin waktu araweng, simbol lontara dan gambar merujuk pada kualitas waktu lobbang; simbol $\mathrm{H}$ Daud dan simbol $\mathrm{Hj}$ Nursiah merujuk pada kualitas waktu mallise; simbol matematika, simbol komputer, simbol aksara Suwandi, simbol bendera merujuk pada kualitas waktu salama; sementara simbol lontara merujuk pada kualitas waktu uju.

Demikianlah perbedaan antara satu simbol dengan simbol lainnya berdasarkan perhitungan waktu hari Senin. Hal ini tentu berbeda jika perhitungan waktunya hari Selasa, Rabu, Kamis, Jumat, Sabtu, dan Ahad.

Tradisi perhitungan waktu yang dikenal dengan hari baik dan hari buruk tidak hanya ditemukan pada masyarakat Bugis Kendari, tetapi juga masyarakat di hampir seluruh Indonesia. Masyarakat Buton di Kendari (Burhan, 2013) dan Bugis di Sulawesi Selatan dan Sulawesi Tenggara mengenal tradisi ini dengan istilah Kutika (Gunawan, 2014). Di Jawa, masyarakatnya mengenal istilah Pranata Mangsa. Pranata Mangsa berfungsi untuk memberikan pedoman kepada masyarakat untuk melakukan segala aktivitas. Pedoman ini dapat ditemukan di dalam Primbon (Woodwark, 2004). Di Sumatera Utara, orang Batak memiliki istilah Porhalaan (Kristoko dkk, 2012). Di Bali, tradisi ini dikenal dengan istilah wariga (Simpen, 1987; Wisnubroto, 1999). Di Kalimantan Barat, masyarakat Dayak mengenal tradisi Bulan Berladang (Muryanti dan Rokhiman, 2017).

Meskipun perhitungan waktu untuk menentukan hari baik dan hari buruk di hampir semua suku di Indonesia sama dalam perspektif kosmologi, namun perbedaannya terletak pada penggunaan simbolnya. Penggunaan simbol ini tentu berkaitan erat dengan kondisi sosial budaya setempat. Jika masyarakat Bugis Kendari menggunakan 11 simbol, seperti simbol lontara, bintang, dan hewan karena masyarakat Bugis yang memiliki aksara lontara adalah masyarakat pelaut yang dekat dengan alam sehingga memanfaatkan hewan dan bintang dalam mencari ikan, maka masyarakat Jawa menggunakan simbol wayang, mata angin, bunga, pisau belati, dan primbon dan masyarakat Bali menggunakan simbol meteorologi (Simpen, 1987).

Tradisi perhitungan waktu ini tidak hanya ada di Indonesia, tetapi juga di Eropa, Amerika, Inggris, China, India dan Arab. Masyarakat Arab yang tinggal di daerah pedesaan masih memiliki keyakinan bahwa bulan Safar adalah bulan ketidakberuntungan. Hal ini kemudian membuat mereka tidak melakukan kegiatan-kegiatan penting, seperti mengadakan pesta pernikahan, banyak beperjalanan, dan melakukan bisnis dalam bulan tersebut (Luling dan Adam, 2015). Ada juga di antara mereka yang masih memiliki keyakinan bahwa hari baik dan hari buruk dapat ditentukan dengan melihat arah burung yang melintas di hadapannya. Jika arah burung berasal dari kanan, mereka akan pergi keluar rumah untuk berdagang. Sebaliknya, jika burung datangnya dari arah kiri, mereka akan mengurungkan niatnya untuk melakukan bisnis. Bahkan, ketika mereka sudah keluar rumah dan sementara dalam perjalanan menuju suatu tempat dan melihat burung datang dari arah kirinya, maka mereka akan kembali ke rumahnya untuk menghindari hari nahas (Luling dan Adam, 2015). Tradisi masyarakat Arab dulu ini senada dengan masyarakat India. Mereka berkeyakinan bahwa tanggal 1 hingga tanggal 13 bulan Safar adalah hari ketidakberuntungan yang akan membawa bencana, malapetaka dan membuat semua usaha menjadi sia-sia (Mazaheri dan Dalfard, 2015).

Berbeda dengan masyarakat Indonesia, Arab dan India, perhitungan hari baik dan hari buruk di China, Eropa dan Amerika memiliki keunikan tersendiri. Di China, masyarakat menggunakan 
simbol bilangan (Wang, 2006) dan warna (Kramer dan Block, 2008) untuk menentukan hari baik dan hari buruk. Warna merah dianggap sebagai hari buruk dan warna celaka, sementara di Amerika dan Eropa menganggap warna hitam sebagai warna celaka dan ketidakberuntungan. Di China, angka keberuntungan adalan angka 3, 6, 8, dan 9, sementara angka 4 dan 7 dianggap sebagai angka sia (Bai dan Guo, 2010). Hal ini karena angka bilangan dan suara kata keberuntungan dan ketidakberuntungan memiliki kesamaan. Di China, angka 4 disebut si. Kata si ini bermakna kematian. Sebaliknya, angka 3 dan 7 dianggap sebagai angka keberuntungan. Bilangan 3 dianggap angka keberuntungan sebab mereka mengasumsikan bahwa dunia disusun dari macam item; tanah, laut dan langit dan 3 sumber daya alam; binatang, tumbuhan dan mineral. Mereka memiliki istilah "the third time is the carm", "number three is always fortune" (Bai dan Guo, 2010). In addition, Shakespeare memiliki istilah tersendiri "All good things back to the three standards" (Hariyanto, 2013).

Di dalam budaya Barat, masyarakat tidak menggunakan angka 2 dan 13 karena 2 merupakan bentuk jamak dari kata die yang bermakna kematian. Angka 13 dianggap sebagai simbol berbahaya bagi negara. Di Inggris dan Amerika, ada ungkapan yang mengatakan bahwa "thirteen is an unlucky number." Angka 13 adalah angka ketidakberuntungan. Di Inggris dan Amerika, ruangan hotel dan rumah sakit tidak memiliki angka 13. Nomor rumah juga tidak menggunakan angka 13 (Puryandani, 2015; Westjohn, Roschk, dan Magnusson, 2017).

\section{PENUTUP}

Penelitian ini menegaskan bahwa perhitungan waktu hari baik dan hari buruk dapat ditemukan tidak hanya hampir pada semua suku di Indonesia, tetapi juga di belahan dunia lainnya, seperti Arab,
India, China, Eropa, Inggris, dan Amerika. Namun demikian, simbol yang digunakan untuk menentukan hari baik dan hari buruk tentu berbeda-beda karena perbedaan sosial budaya, agama, dan lingkungan setempat. Untuk masyarakat Bugis Kendari, ada 11 simbol yang digunakan untuk menentukan hari baik dan hari buruk, yaitu (1) simbol bahasa Arab, (2) simbol matematika, (3) simbol tulisan tangan, (4) Simbol lontara bugis, (5) simbol lontara Bugis dan gambar, (6) simbol aksara Soewandi, (7) simbol hewan, (8) simbol bintang, (9) simbol bendera, (10) simbol haji Daud, dan (11) simbol Hj. Nursiah. Namun secara garis besar, pedoman simbol itu diklasifikasi berdasarkan waktu ele (pagi), abueng (duha), tangasso (tengah hari), loro (siang), dan assara (sore) pada hari asseneng (Senin), salasa (Selasa), araba (Rabu), kammisi (Kamis), juma (Jumat), dan sattu (sabtu) dan kualitas waktu, seperti mate (kematian), tuwo (kehidupan), maddara (berdarah), lobbang (pulang pokok) dan mallise (berisi). Dalam hal ini, semua masyarakat Bugis Kendari akan memilih untuk memulai sebuah aktifitas pada kondisi tuwo (kehidupan) dan mallise (berisi) dan sebaliknya, tidak akan memilih memulai mengerjakan suatu pekerjaan pada kondisi mate (kematian) dan maddara (berdarah). Hal ini disebabkan karena adanya keyakinan kuat yang mengatakan bahwa mereka akan mendapatkan keuntungan, kebahagian, kesenangan, kebaikan jika menggunakan kualitas waktu mallise dan tuwo, dan sebaliknya mereka akan mendapatkan abalang (malapetaka) dan musibah jika menggunakan waktu maddara dan mate. Di era millineal, keyakinan itu masih lekat dalam sanubari orang tua kita atau generasi di atas 50 tahun ke atas, sementara generasi muda saat ini belum bisa menentukan sikap mereka yang terkadang mengikuti perintah orang tua dan terkadang pula tidak dalam hal menggunakan pedoman simbol hari baik dan hari buruk. Penelitian ini masih jauh 
dari kesempurnaan. Sampel data penggunaan pedoman simbol hari baik dan hari buruk hanya terbatas pada kecamatan tertentu di kota Kendari. Dengan demikian, penelitian ini dapat diperluas jangkauannya ke kota-kota kabupaten sebagai basis orang Bugis di Sulawesi Tenggara, seperti Bombana, Kolaka, Kolaka Utara, Desa Tinobu Konawe Utara untuk melihat lebih jauh bagaimana masyarakat Bugis di lokasi tersebut memperlakukan simbol dan meyakini apa yang terdapat di dalam simbol itu. Selain itu, penggunaan simbol itu dapat dikaitkan dengan simbol menolak bala dan dikaji dalam perspektif Islam.

\section{DAFTAR SUMBER}

\section{Jurnal}

Hariyanto, H. Y. 2013.

"Pandangan Mahasiswa Universitas Kristen Petra terhadap Angka Sial dan Angka Keberuntungan". Dalam Century, Vol. 1, No. 1.

Kamaluddin, A., Nurdiah, H., Nurbaya, B., Saleh, S. 2016.

"Pananrang": A Guidance of Bugis Farmers in Farming". Dalam International Journal of Agriculture system, Vol. 4, No. 2, hlm. 168-177.

Kramer, T, and Block, L. 2008.

"Conscious and Unconscious Components of Superstitions Belief in Judjement and Decision Making". Dalam Journal of Consumer Research, Vol. 34, hlm. 783-794.

Kristoko, H., Eko, S., Prasetyo, S.Y. and Simanjuntak, B., 2012.

"Updated Pranata Mangsa: Recombination of Local Knowledge and Agro Meteorology using Fuzzy Logic for Determining Planting Pattern". Dalam International Journal of Computer Science Issues, hlm. 16940814.

Luling, V. and Adam, A.S., 2015.

"Continuities and changes: Marriage in southern Somalia and the diaspora.
Dalam Northeast African Studies, Vol. 15, No. 1, hlm. 139-165.

Mazaheri, A.M.A. and Dalfard, N.S., 2015. "Anthropological Recognition of Customs and Traditions of Mate Selection in Sirjan, Iran". Dalam European Online Journal of Natural and Social Sciences, Vol. 4, No. 3, hlm. 536.

Munawwar, A. R. 2012.

"Komparasi Lontara Pananrang dengan Pendapat Imam Ja'far al-Shadiq tentang Hari Baik dan Hari Nahas". Dalam Jurnal Qurba, Vol. 2, No. 3, hlm. 270291.

Muryanti, M. and Rokhiman, R., 2017. "Bambi Ari'sebagai Wujud Kearifan Lokal Masyarakat Dayak Dalam Penanganan Bencana Kabut Asap Di Kabupaten Kapuas Hulu, Kalimantan Barat". Dalam Jurnal Sosiologi Reflektif, Vol. 11, No. 1, hlm. 21-39.

Puryandani, S., 2015.

"The Javanese Lunar Calendar's Effect on Indonesian Stock Returns". Dalam Gadjah Mada International Journal of Business, Vol. 17, No. 2, hlm. 125.

Yusmar, S. 2008.

"Penanggalan Bugis-Makassar dalam Penentuan Awal Bulan Kamariyah menurut Syari'ah dan Sains". Dalam Jurnal Hunafa, Vol 5, No. 3 Desember, hlm. 265-286.

\section{Buku}

Bai, C. Y and Guo Y. R. 2010.

Zhong Xifang Shuzi Wenhua Chayi. Henan: Henan Keji Xueyuan Xuebao.

Burhan. 2013.

Effort on Climate Change Adaptation Determination Early Season Planting Time (Buton Community Local Wisdom. Dalam The International Conference on Climate Change and Local Wisdom: Living in Harmony within Our Environment, Makassar: The Department of Architecture Alauddin State Islamic University Makassar.

Effendy, O. U. (1989).

Kamus komunikasi. Bandung: Mandar Maju. 
Gunawan, F. 2014.

The Prophetic Spirit in Lontara Pananrang Script at Islamic Bugis Society. Dalam International Conference on Islamic Civilization: I'adat Tafsir Al-Sirah an-Nabawiyyah fi Daui at-Taqaddum al-Basyary. Yogyakarta: Aura Pustaka.

Gunawan, F. 2015.

Good and Terrible Days Symbols in Pananrang Manuscript: Cultural Linguistic Persepective. Dalam The $2^{\text {nd }}$ International Seminar on Linguistics. Padang: Postgraduate Programe on Linguistics Andalas University and Linguistics Society of Indonesia Universitas Andalas.

Koentjaraningrat. 2009.

Pengantar Ilmu Antropologi. Jakarta: Rineka Cipta.

Lathief, H. 2005.

Kepercayaan Asli Bugis di Sulawesi Selatan. Makassar: Program Pascasarjana Universitas Hasanuddin.

Mahsun. 2005.

Metode Penelitian Bahasa: Tahapan, Strategi, Metode dan Tekniknya. Jakarta: PT Raja Grafindo Persada.

Miles, M. B., and Huberman, A. M. (1984). Qualitative data analysis. Beverly Hills.

Riley, P. 2007.

Language, Culture, and Identity, London: Continuum.

Santosa, R. 2012.

Metode penelitian kualitatif kebahasaan. Surakarta: UNS.

Simpen. 1987.

Pelajaran Wariga. Denpasar: Toko Buku Munia.

Siregar, N. S. S. 2016.

Kajian tentang Interaksionisme Simbolik. Perspektif, 4(2).

Wang, P. 2006.

Xieyin Jinji de Wenhua Xinli Toushi. Beijing: Ningbo Daxue Wenxue Yuan.

Wisnubroto, S. 1999.

Pengenalan waktu tradisional pranata mangsa dan wariga menurut jabaran meteorologi: manfaatnya dalam pertanian dan sosial. Mitra Gama Widya.

Woodward, M. R., \& HS, H. S. 2004.

Islam Jawa: Kesalehan Normatif Versus Kebatinan. Yogyakarta: LKIS. 